\title{
THE INTELLECTUAL-THEOLOGICAL LEADERSHIP OF JOHN AMOS COMENIUS
}

\author{
JUSTIN L. GLENN*
}

Children's of Alabama Hospital

\begin{abstract}
John Amos Comenius was a revolutionary leader in both the church and the academy in 17th century Europe. Born and raised in Moravia and firmly grounded in the doctrine of the United Church of the Brethren, Comenius rose from obscurity in what is now the Czech Republic to become recognized around Europe and beyond as an innovative and transformational leader. He contributed to efforts such as advocating for universal education, authoring classroom textbooks (most notably in Latin education), shepherding local churches and his entire denomination, and working for unity and peace among Christians across Europe. Though for many decades after his death he seemed to be lost to time, there has been a resurgence of scholarly interest in the ideas and methods of Comenius. His life and work can serve as a source of encouragement and inspiration to church and educational leaders today.
\end{abstract}

KEYWORDS: John Amos Comenius, Jan Komensky, educational leadership, Brethren, Christian leadership

Some great leaders in history are easily recognized for their bold and farreaching achievements. Some immediately draw great numbers of followers and initiate change in their field without restraint. Due to a number of reasons, however, others may be lost to future generations. Without doubt, there are countless faithful and gifted Christian leaders who served the church throughout the centuries whose names have not been known for generations. John Amos Comenius, seventeenth century Brethren pastor and educator, was one such leader whose influence became lost to history. Jaroslav Pelikan called him a 'distinguished catastrophe' (1992: 7) due to his great genius that existed in a very difficult time and was lost for many years. Apart from some language textbooks, Comenius's work, and most importantly his works on educational philosophy and universal reform, was almost entirely unknown for almost two centuries after his death. A few

* JUSTIN L. GLENN (EdD 2017, The Southern Baptist Theological Seminary) is independent researcher and writer. Email: glenn.justin@gmail.com. 
scholars began studying Comenius's work in the late nineteenth century, but his wide-spread rediscovery did not occur until the twentieth century.

In a previous article, I noted that Comenius's rediscovery by secular educational theorists Jean Piaget and Vladimir Jelinek was ultimately misguided by their anti-supernatural bias (Glenn 2016) and resulted in a deficient interpretation of Comenius's work. Instead, I argued that Comenius, as well as any other writer from a different time and/or culture, should be read carefully in context, including giving the historical figure's religious and philosophical beliefs proper credit for his or her thought and work. In Comenius's case, a contextual approach requires reading him theologically. Every educational and political position he takes is grounded in his theology, and unless the reader recognizes this fact and interprets accordingly, misunderstandings are almost certain. It is impossible to understand, for example, Comenius's revolutionary notion of universal education (for both sexes and for all socio-economic classes) without taking into account his biblical anthropology. He did not argue for universal education because of a secular social agenda, but because he believed that each human being was created in God's image and was worthy of dignity. For Comenius, dignity meant being afforded whatever educational opportunities were available.

Though perhaps still not well known by many Christians, Comenius's life and work provide an excellent example of intellectual-theological leadership in the church. In addition to theorizing about progressive ideas such as universal education, Comenius provided leadership to individual schools and churches, and he provided resources and models for any who explored his writings. Comenius lived during a tumultuous time, and he suffered many setbacks due to war, political conflict, and nationalistic upheaval. Amid all of this, however, his legacy serves current and future generations of Christian leaders by displaying persistence in hardship, faith and hope in God, and an unwavering pursuit of the ideals that he was confident would both honor God and benefit God's people. In this article, I will apply my previously stated contextual and theological reading of Comenius to examine his intellectual-theological leadership.

\section{Biographical Background}

John Amos Comenius was born on March 28, 1592 amid the religious and political conflicts of Moravia, now part of the Czech Republic. The tensions that were building at the time would eventually lead to the Thirty Years' War, a devastating event for Comenius, his family, and the people of the region. Comenius described his poor and often harsh childhood education in The Labyrinth of the World and the Paradise of the Heart, a largely autobiographical work. Murphy explains that Comenius recorded the nature of his childhood education as "harsh and brutal, its hallmark being the repeated 
infliction of physical punishment on the young pupils' (Murphy 1995: 9). Likewise, William Filkin notes that his childhood education was only 'meager' (1975: 177), which would, no doubt, be a source of inspiration for his future educational reform work.

At sixteen, as he recounts, his true education began when he was first introduced to Latin, which would become a central discipline in his educational career. In his Latin studies, he saw the frustration of learning this language by the mostly younger boys in his class (girls were not allowed a Latin education at that time) (Robinson 1998: 48). Seeing their struggle helped to spark the notion of educational reform in Comenius's mind. By 1614, he had received theological training at several schools, culminating at the University of Heidelberg. During this period of higher education, he spent time under the influence of famous theologians and educational reformers (Murphy 1995: 10; Filkin 1975: 177). Immediately upon completion, Comenius began teaching and writing resources for Latin education. Two years after his completed his education, he was ordained in the Brethren church and was appointed as a pastor. At this time, Comenius's career appeared predictably within the realm of pastoral leadership with an interest in Latin education as well. He spent two years at his first church in Olmutz, followed by a pastorate in Fulneck. It was during his time in Fulneck that he became more involved in educational leadership when he was appointed as Rector of a local school (Murphy 1995: 10-11; Gundem 1992: $45)$.

Over the next eight years, the situation in Moravia became more and more unstable, forcing the Brethren to make a choice to either stay and pursue stability or move and find refuge elsewhere. As a result of the invasion of Spanish troops into Moravia, Fulneck was destroyed, including Comenius's house, in which he lost his library and most of the work he had done over the past few years. In 1628, after several years of discussion and exploration, the Brethren leadership decided that the clergy could not remain in Moravia, so they moved to Lezno, Poland to avoid persecution. Price describes their situation succinctly:

This war was part of the Reformation turmoil; and in these countries, it resulted from conflict between the Catholic power supported by the Hapsburgs, the Inquisition, and the Jesuits, and the Protestant objection to it fostered by local nobles, merchants, and others involved in the rising nationalisms. Comenius found himself a citizen of a devastated country, and a pastor in a persecuted sect which, while it aspired to freedom of worship if not to the status of a religion established by an independent national government in Moravia and Bohemia, was early in the conflict exiled from its native land (Price 1962: 178). 
Comenius settled in Lezno, hoping for a temporary exile from his homeland. He longed to return to help with the work of rebuilding Moravia and the educational system there. Perhaps as a preparation for that task, he began work on his most well-known book, The Great Didactic. As a result of his early works, Comenius became known in many parts of the world for his educational ideas, and his books were translated into many languages and spread around the known world (Price 1962: 178; Robinson 1998: 47). When Comenius left for his exile, his wife and two sons remained in Fulnek. He wrote to them, even writing a pamphlet for his wife meant to give her hope in the midst of this difficult time. Eventually, word reached Lezno that his wife and sons had died, probably as a result of a plague brought by soldiers (Bock 1970: 12; Robinson 1998: 46, Filkin 1975: 178). His return to Moravia seemed wholly unlikely by this point.

While Comenius spent many of the years between 1628 and 1656 in Lezno, it was interspersed with time spent in other countries (Hábl 2015: 116). In 1641, he was invited to come to London by the British government to help with reforming their educational system. Word had spread about his unique ideas and abilities, and, in fact, he turned down an invitation at this time to come to Harvard University in America to aid in the outreach to and education of Native Americans (Murphy 1995: 27-28). His visit cut short the next year by a civil war that broke out in England, Comenius was then invited to Sweden with the same goal in mind. He spent 1642-1648 in Sweden, working for educational reform despite much opposition and difficulty (Murphy 1995: 32-33). His third excursion from Lezno occurred in modern-day Hungary, where he was again invited to reform the schools (Hábl 2015: 116; Murphy 1995: 36). Like in his other efforts, he faced significant opposition by powerful leaders in his reforming efforts. While he saw some success, his influence did not reach beyond his immediate context, besides some of his written works that were well circulated (Murphy 1995: 39-40). Returning to Lezno for the final time in 1654, Comenius only spent two more years there before the Polish army invaded the city (Robinson 1998: 47). His house was burned, along with all of his work that resided there (Filkin 1975: 179). The intellectual loss in this tragedy was catastrophic for the promulgation of Comenius's work. Every manuscript he had written over the previous 40 years was lost, including many unpublished works such as his Czech-Latin dictionary (which he worked on for all of those 40 years) and his unpublished work on pansophia, or universal education (Murphy 1995: 40; Hábl 1975: 116).

Once again forced into exile, Comenius moved to Amsterdam where he spent his last years. He never ceased in his work for educational reform and unity among the various strains of Christianity in whatever region he resided. He continued to produce material for both purposes, and he continued 
to hope for systemic change to come to Moravia, his beloved homeland, as well as to the rest of Europe. In 1670, the world lost an educational leader who strove to make each of the many locations in which he lived a better place. Regrettably, Pelikan's 'distinguished catastrophe' seems to be an appropriate title for this man who, in the midst of constant opposition and the ravages of war, gave his life for the betterment of the church and of society as a whole.

\section{Elements of Comenius's Intellectual-Theological Leadership}

The brief biographical sketch above serves to provide a framework for understanding Comenius's intellectual-theological leadership throughout his life. Born into a region and a time that had recently witnessed the Hussite Reformation and a continent that was violently divided by religious-political lines, Comenius was a figure that might be described as desperately needed, yet severely underutilized, in his lifetime. In his nearly eighty years, Comenius charged ahead by lending his intellectual-theological leadership in many locations and in many ways. Four primary areas where Comenius's unique leadership can be seen are in his writings, his educational reform efforts, his pastoral work, and his repeated attempts to help unify the disparate factions of Christians throughout Europe.

\section{Most Significant Writings}

John Amos Comenius was a prodigious writer from the very beginning of his career. A primary source of joy appears to be writing books and resources that would help teachers educate children well. One of his first publications, Irenium, came before he finished his own education, and in it he 'urged Lutheran, Calvinist, and Bohemian Protestants to come together at a general synod and to find ways of resolving their theological differences' (Murphy 1995: 10). He published his first school textbook, Principles of a Simpler Approach to Grammar, only two years after he completed his studies (Hábl 2011: 111). His production of written material never ceased, and he is the author of 'about 200 books mainly on educational and didactic subjects' (Hábl 2011: 43). Though educational reform occupied much of his thinking and writing, he also addressed many other subjects in his written work. A few of the most significant and far-reaching works produced by Comenius include The Labyrinth of the World and the Paradise of the Heart, The Great Didactic, Pampaedia, The Gates of Languages Unlocked, World in Pictures, and Panorthosia.

The Labyrinth of the World and the Paradise of the Heart. This early work of Comenius's sheds light on his childhood education and some of the reasons he became so interested in educational reform. His Labyrinth was largely an 
autobiographical allegory that has received great critical acclaim among Czech literature of that period (Murphy 1995: 13). The work as a whole was similar to John Bunyan's Pilgrim's Progress in that it was the story of a traveler who encountered all that the world had to offer but found it lacking (Hábl 2011: 46). Within the allegory, Comenius expounds on his childhood education, and he described the students repeatedly receiving painful punishments and treatments:

Just then I looked and perceived how dearly those poor wretches had to pay for their re-formation: I do not speak of their purses, but of their skins which they had to expose. For they were fisticuffed, beaten with pointers, canes, and sticks on their cheeks, head, back, and seat until they shed blood, and the majority of them were full of bruises and scars, wales and calluses. Some seeing this, before they surrendered themselves, cast a hasty glance inside the gate and ran away. Others tore themselves out of the hands of the would-be re-formers and likewise fled. Only a small remnant persevered to the end, and those were allowed to proceed further to the square (Comenius 1942: 37).

Notably, the solution to the disillusionment of the traveler comes in the form of glasses by which he can accurately see reality. Hábl rightly concludes that this solution exhibits Comenius's understanding of the role of God's grace in a sinful world of suffering (2011: 46). The solutions to the world's educational problems, while perhaps enacted through humans means, are enabled wholly by God's grace.

The Great Didactic and Pampaedia. The Great Didactic was perhaps Comenius's most important book regarding educational philosophy (Adamson 1921: 48). He completed it early in his career (early 1630s), but it was only published in a Latin edition in 1657 in his lifetime (Murphy 1995: 15). It was not published in a vernacular language until 1849, more than 200 years after its writing (Kinloch 1969: 51). The first few chapters of The Great Didactic establish Comenius's educational philosophy as grounded in a biblical anthropology that understood the universal dignity of humanity as created in God's image. All of the educational ideas he fought for-including universal education, focusing more on the needs of the learner, and providing a comprehensive liberal education-stemmed from his biblical convictions (Glenn 2016: 192). The subtitle to The Great Didactic is helpful for understanding his intention:

The whole Art of Teaching all Things to all Men, or A certain Inducement to found such Schools in all the Parishes, Towns, and Villages of every Christian Kingdom, that the entire Youth of both Sexes, none being excepted, shall Quickly, Pleasantly, \& Thoroughly Become learned in the Sciences, pure in Morals, 
trained to Piety, and in this manner instructed in all things necessary for the present and future life.

His intellectual leadership was firmly rooted in his theology, and The Great Didactic is a prime example of Comenius's intellectual-theological leadership.

Comenius's Pampaedia remained merely an undiscovered manuscript until the 1930s (Hábl 2011: 102-103). It is the fourth volume of a larger work that was first published in 1966 in Latin (Smith 2000: 208-209, footnote 8). There is definite overlap between The Great Didactic and Pampaedia. and Hábl describes it as such: 'What was implicit in the early Didactics is made explicit in the later Pampaedia' (2015: 118). In his Pampaedia, Comenius expounded on his initial thoughts of universal education from The Great Didactic. The ideas that were largely theoretical in his early career could now be explained more fully as a result of his experience in applying them to educational resources and educational settings. In addition to the fuller explanation, Pampaedia included a few alterations to his ideas in The Great Didactic. For example, he first recognizes four stages of development in children, resulting in four school stages, but in the Pampaedia, he extends these stages throughout life by adding four more that follow childhood. This later work shows the development and growth of Comenius's thought, as well as the consistency in principle, throughout his life.

The Gates of Languages Unlocked and World in Pictures. When Gates was published in the early 1630s, its popularity surprised Comenius (Hábl 2015: 116). It was eventually translated into sixteen languages and went through over one hundred editions, resulting in his international fame (Bock 1970: 12; Gangel and Benson 1983: 155-156). Upon seeing its popularity, he produced two accompanying texts that were age-graded for elementary and advanced students (Hábl 2015: 116). With these works, he intended to simplify the learning of Latin, a discipline that he prized as crucial to a sound education (Robinson 1998: 47). His leadership in the area of language learning still commands the attention of language education scholars and is one of the primary pedagogical legacies that Comenius has left. (See the work of Jan Habl (2015) and David Smith (2000) for helpful modern examinations of Comenius's work with language education).

Later in his career, Comenius produced a book that served as a followup to Gates. His World in Pictures is not only important in language learning, but it also was the first textbook to be illustrated (Bock 1970: 12-13). Murphy calls it an 'essentially simplified version of [The Gates of Languages Unlocked]' (1995: 39), but its distinction sets it apart as a unique work of its own. The near universal practice of illustrating modern children's textbooks had its beginning in this seventeenth century work of Comenius. This inno- 
vation in language pedagogy was revolutionary in Comenius's time, and it is taken for granted in modern times as the best practice for primary education.

Panorthosia (Universal Reform). Comenius not only pushed for educational reform, but also for what he called universal reform in his Panorthosia, written about a decade before his death. He recognized the dark and sinful state of the world, and he intended to begin the search for a comprehensive plan to reform it. In this universal reform, Comenius argued for a logical sequence:

Then if the reform of human states is to become possible, we must reform the individuals who comprise them. In the case of men, we should begin by reforming schools which are the factories of men; in the case of schools, we should reform books, as being the appropriate instruments for the formal education of men; in the case of books, we should reform the method of writing and producing them; and finally to enable us to reform the method fully, we must attend to the order of the material world itself, which cannot be moved since it has been framed by the skill of God and has unchangeable laws to prescribe for human understanding (Comenius 1993: 15).

While Comenius's life was largely spent thinking about and attempting to achieve reform in education, he understood educational reform to be merely the first step to universal reform. He desired to see the whole world, at both the national and individual levels, transformed by the gospel. While his vision may be seen as idealistic and unattainable, perhaps especially because of the conflict that was present around him, he nonetheless strove for these ideals throughout his life.

\section{Educational Reform}

Not only did Comenius write about educational reform, but he also practiced it when the opportunity afforded itself. Due to the previously mentioned turbulent state of his region, Comenius had to flee warzones and political unrest more than once. Additionally, he accepted invitations from leaders of other nations to come lead in their own educational reform efforts. Comenius's active educational career began about four years after completing his formal education, when he became pastor at Fulnek. In addition to his pastoral duties there, he was also appointed as the Rector of the local school (Murphy 1995: 11). His years there were constantly overshadowed by the recently erupted Thirty Years' War, and thus his hopes for significant reform did not happen as he may have wished.

Several years later, at the beginning of his exile in Poland, Comenius began helping with the education of the children in the family who gave him 
refuge. This inspired further thought about education and led to the writing of one of his most important educational philosophy works: The Great Didactic. About this time, he moved away from the family who initially gave him refuge and into the city of Leszno where he was placed in a position of academic leadership. It was here that he earnestly began attempting the reform that he had been writing about. His work here centered on Latin education, out of which came his The Gates of Languages Unlocked, a Latin language teaching text that departed from the traditional pedagogical practices to forge new ground (Hábl 2015: 116-117). More Latin texts followed as a result of his educational leadership in Leszno, forming a graded system of Latin education that was like no other in existence. He earned praise from around Europe and even as far away as America for Gates, and it was translated into a number of languages. This is perhaps the most practical impact that Comenius had in education as his Gates became the standard Latin text in the Western world for several generations (Murphy 1995: 1417).

After his fruitful time in Leszno, publishing educational texts and enacting educational reform at the local school level, the renown of Comenius began to attract attention from leaders of other nations (Hábl 2011: 32). In 1641, he received an invitation from the English Parliament to come and help lead educational reform efforts there. Though he was offered a permanent position and salary in England, his time there would be short due to the outbreak of another war. During his short stay, he made plans for a 'pansophic' college to be established that would utilize his pansophic philosophy and teach a broad liberal arts curriculum with the notion that all knowledge is interrelated at the core. (For an explanation of pansophy, see below in the section: 'Efforts toward Unity'.) The school was indeed opened, but not until many years later (Filkin 1975: 178; Robinson 1998: 47; Murphy 1995: 28). With the outbreak of war, as well as shifts in political power, Comenius found his work in England nearly impossible. In 1642, he was issued an invitation to come to Sweden to lead in educational reform.

During his journey to Sweden, Comenius met with several people of great renown in an effort to create a group of scholars from around Europe to aid in his universal reform efforts (Hábl 2011: 36-37). He apparently even met with Rene Decartes, but nothing ever came of these meetings (Hábl 2011: 37, footnote 102). The Swedes, upon hearing Comenius's educational reform ideas in person, made a generous offer to financially support both him in his efforts there as well as his Brethren community who remained in Leszno. Comenius accepted the offer. His primary role for the next six years was producing new textbooks, based on his prior pedagogical innovations, to be used in Swedish schools (Eby 1952: 180; Hábl 2011: 37). Like before, Latin was the subject he was most passionate about, and he 
wrote several Latin texts for the Swedish schools. Regrettably, but seeming to form a pattern for Comenius's educational efforts, he began to experience opposition. This time it was not war, but it was a Lutheran pastor who charged Comenius with trying to sneak Calvinism into Sweden by way of his texts. As a result, he left Sweden and eventually made his way back to Leszno (Murphy 1995: 31-33).

Yet another invitation to lead in educational reform efforts came from Hungary in 1649. He moved there in 1650 to take leadership of the gymnasium at Sáros Pátak and to consult with Hungarian educational leaders. Upon arrival, he proceeded to aggressively initiate reform at his gymnasium. Laying out a comprehensive plan for reform, Comenius encountered resistance from the faculty and administration of the school (Hábl 2011: 39). Prince Sigismund Rákóczy, the man who initiated Comenius's invitation and ordered the school's faculty to cooperate with his reforms, died in 1654, removing Comenius's support in Hungary (Murphy 1995: 38-39). He saw some success in his local school in Sáros Pátak, but he failed to influence the broader Hungarian educational system as he had hoped. In 1655, he left Hungary to return to Lezno. His Hungarian efforts were his last in terms of actively leading educational institutions. He would still write more textbooks and pedagogical works, but he would not attempt to enact his pansophic vision in another local school. His dreams of a truly reformed school never came to fruition, but he did have a lasting impact on Latin education for many generations, as well as on Christian educational philosophy after the rediscovery of many of his works and activity in the 19th and 20th centuries.

\section{Pastoral Leadership}

Amid all the work that Comenius did in education, he served faithfully as a pastor and Bishop in the Brethren church. Upon completing his formal education, he was ordained as a minister in the Unitas Fratrum Bohemorum, or the Church of the Bohemian Brethren (Hábl 2011: 111; Falkner 2001: 159). His first pastorate was in Olmütz, and he spent two seemingly quiet years there. He then moved to Fulneck where he concurrently served as pastor at the church and rector at the school (Murphy 1995: 11). He spent several years here until the outbreak of the Thirty Years' War. It appears that his service was forced to become sporadic as the Brethren clergy were often in danger of religious persecution. Eventually, they decided that it was time to leave Bohemia and seek refuge in Poland.

In exile in Leszno, Poland, Comenius served as an educational leader and as a minister (Hábl 2011: 33-34). In 1632, he was elected as a Bishop and Secretary of the Commission. In this role, he would be the spokesperson, of sorts, for the doctrine and teaching of the Brethren church. He took 
this responsibility on and also produced a few texts specifically for the Brethren (Hábl 2011: 33). Additionally, he used his new position to work for unity beyond the Brethren, reaching out to Protestants of all types (examined in more detail below) (Murphy 1995: 18).

Beginning in 1641, his duties as pastor and bishop were temporarily halted as he accepted invitations to various countries over the next 14 years (Hábl 2011: 33). Throughout his time away from the Brethren and his family, he longed to be back with them, serving in the role of pastor and denominational leader as he had planned (Murphy 1995: 30). He appears to have felt it necessary to pursue his educational reform in a broader context, but he always hoped to return to Leszno, and eventually to Bohemia (though this would never occur), to resume his service as a pastor and bishop.

In 1648, he returned to Leszno for a brief respite from his travels. Upon arrival, he was elected Senior Bishop of the Unity Church. With the end of the Thirty Years' War and the declaration that Roman Catholicism was the official religion of Bohemia, he convened a meeting of the Brethren to discuss their future (Murphy 1995: 33). He provided leadership to the Brethren churches in a time of great distress, and he called on all Christians to unify in the midst of so much division. He spent less than a year in Leszno as the Senior Bishop, and he accepted an invitation from Hungary to help lead educational reform there.

In 1655, after his time in Hungary came to an end, he returned to Leszno and again took up the responsibilities of a pastor. Very shortly thereafter, the liberating Protestant Swedish army invaded Poland but was defeated by the Catholic King John Casimir (Murphy 1995: 40). Leszno, being a largely Protestant town and having Protestant nobles, was targeted for destruction by the Polish army (Hábl 2011: 40). Comenius lost everything and eventually ended up in Amsterdam where he would live the rest of his life. His pastoral work was finished, but he would continue writing until the end of his life, not only concerning education and reform, but also as a continuing shepherd from afar. For example, Campi examined the previously nearly untouched anti-Socinian essays the Comenius penned between 1659 and 1662 in Amsterdam (2014: 261-283). Though he did not have a specific flock to shepherd anymore, Comenius continued his care for the church and for the purity of Christian doctrine.

Comenius's pastoral work was often interrupted and put on hold because of the demand for his educational leadership abroad. Despite this, he rose to a position of great responsibility as the church recognized his capacity for leadership. As a leader in the Brethren church, Comenius worked to secure the Brethren people in a time of great uncertainty, and he tried to bridge gaps between the various branches of Protestant churches in Europe. 
While ultimate success may have eluded him, he provided a unique brand of leadership that depended on his intellectual acuity and was grounded in his theological concern for the unity of the church.

\section{Efforts toward Unity}

Besides writing, enacting educational reform, and serving as a pastor, the cause of unity among Christians from various branches of Protestantism was a recurring theme in Comenius's life. While most academic attention has been paid to his educational writings and practices, there is evidence that Comenius, himself, understood his educational work as merely a step on the way to Christian unity and harmony. He dreamed of a day when Calvinists, Lutherans, Brethren, and all other Christians who held orthodox Protestant (Reformation) doctrines would be united in purpose without the heated division that was present in his day. The seventeenth century church was full of passionate crusaders for truth, leaders who had a particular theological or ecclesiological vision, but some may say that it actually needed more level-headed, unifying personalities who sought to bring together rather than separate. Comenius's vision was for the church to unify around a few central doctrines that all orthodox Christians share in common and work to live out a practical faith. Beginning in one his earliest works, The Labyrinth of the World and the Paradise of the Heart, he directly pointed out attitudes of Christian sects that were divisive and hateful rather than loving and unifying (Murphy 1995: 18).

Comenius's notions of pansophy (universal wisdom), the belief that all knowledge in the universe is unified and interconnected and that a true education demanded attention to every discipline, played heavily into every endeavor he chose to enter. At this time in Europe, with religion often being inextricably linked with politics, Protestant unification was not merely theological, but also political. Atwood argues, 'The three most important elements of this pansophic reform were education, religion, and politics' (2009: 367). While many ambitious men may have taken on one of the three to make significant progress in during a lifetime, Comenius saw all three as necessarily interrelated, and he worked diligently in each sphere. To attempt to accomplish the specific vision of unification, he sought to make progress in two primary ways: through writing and active mediatorial work in meetings and conferences convened among church leaders, and also through his educational reform efforts.

Writing and mediatorial work. Comenius, in his hope of Protestant unification, was present at a number of gatherings with representatives from various Reformation streams of theology. His postmillennial hopes of 'the dawning of a new age, when the world would return to the original bless- 
ings of Eden' (Atwood 2009: 372) caused him to be confident in the eventual unification of orthodox Christians, and he sought to do it peacefully and by way of mediation. In the 1630 s, during the first part of his exile in Leszno, Poland, Comenius wrote a work wholly devoted to the unification of Protestants called Haggaeus Redivivus. He called on all orthodox Protestants 'to abandon names such as 〈Hussite〉, ¿Lutheran〉, and 〈Calvinist〉 in favour of the common name of ‘Christian' (Murphy 1995: 18-19). He truly believed that the divisions within Protestantism were the result of misunderstandings that, when remedied, would result in the unification of the true church. Later, in The Way of Peace, he further argued for this unification, seeking a return to the practices of the early church (Murphy 1995: 19).

During his time in England, while his educational reform efforts were stalled by civil conflict and political unrest, Comenius was invited to Sweden to engage in educational reform there. As it happened, he would also have the opportunity to put into practice the unification efforts that he wrote about previously. A Lutheran pastor, also concerned with Christian unity and ecumenism, sought to pull him away from educational work to engage in the work of unity, but Comenius determined that he could do both. He began to call for an ecumenical meeting with representatives from all strands of Christendom-including Protestant denominations, the Roman Catholic Church, Eastern Orthodoxy, and the Coptics. King Wladislaw of Poland did, in fact, call such a meeting, the Council of Orlag, but it was destined for failure from the beginning. A true meeting of all parties seems to have never even occurred, but only separate meetings that did not progress the unification agenda of Comenius (Murphy 1995: 31-32; Hábl 2001: 111).

Shortly after the Council of Orlag, Comenius was appointed as Senior Bishop of the Unity Church in Poland. Upon the signing of the Peace of Westphalia to end the Thirty Years' War, he called a meeting of Brethren leaders to discuss what their actions should be in response to Roman Catholicism being declared as the official religion of their homeland in Bohemia. It became clear that there was no hope for a restored Moravia for the Brethren (Gangel and Benson 1983: 156). Out of this meeting came The Bequest of the Unity of Brethren, authored by Comenius. He urged Brethren, Calvinists, Lutherans, and English Puritans to abandon their divisive activity and work to be unified. After more political disruptions, including the loss of all of his possessions to fire at the hands of the Polish army, Comenius moved to his final home in Amsterdam. Here, he spent his last few years writing, both for educational reform and for unification efforts. He desperately hoped for peace to come to Europe, and he did what he was able to help achieve that. In 1667, he was part of the peace negotiations that ended the Anglo-Dutch war (Murphy 1995: 43). He urged peace in order to pre- 
pare the world for the return of Jesus. Murphy explains, 'To the Churches he offered this motto: 'In all things essential unity; in those less needful (which are called additions) freedom; and in all things love to all'. In its very simplicity his own faith had transcended the complexities-and contradictions-of theological orthodoxy, and had enabled him to reach beyond the conflicts in which Christian Churches had become embroiled' (1995: 43).

Peace by way of education. As noted above, for Comenius, all of his pursuits were interrelated. The unification of the various branches of the church was a step on the way to world peace and the millennial reign of Christ, and educational reform was a step on the way to the unification of the church (Price 1962: 193-194). He truly believed that education had a powerful role to play in bringing about world peace and eschatological paradise: 'Without any exaggeration, for Comenius education plays a soteriological role: it is a God-given means for the salvation of mankind' (Hábl 2015: 126). Comenius argued that 'schools were the workshops of humanity' and that 'man really becomes man, that is to say (to refer to our previous analysis): (1) a rational creature; (2) a creature which is lord over all creatures and also over himself; (3) a creature which is the delight of his Creator. This will be the case if schools are able to produce men who are wise in mind, prudent in action, and pious in spirit' (Comenius 1907: 71). Education was not simply a matter of learning facts and testing well, but for Comenius, education was the whole formation of a human being, training that leads toward living as one who is created in God's image, for the benefit of mankind and the glory of God. From early in his career, he believed that his educational reform efforts were part of something larger than simply producing knowledgeable graduates. As Atwood notes, 'Comenius's pansophic reforms might have been too ambitious for the seventeenth century, and perhaps for the twentyfirst as well' (2009: 397).

\section{Conclusion}

To say that Comenius was not able to accomplish nearly all that he hoped to in the fields of education, religion, and politics would be an accurate summary. To say, however, that he was an unimportant or ineffective leader as a result of that would not. Certainly, in a lifetime shared with such historically significant figures as Shakespeare, Galileo, and Descartes, and living during the beginning of the incredible expansion of the European world into the Americas and beyond, Comenius can be, and has often been, lost in the crowd. But his accomplishments and influence, both on people and institutions in his time as well as far beyond, are undeniably worthy of attention and examination. There is a reason that he has earned descriptions such as the "polymath scholar, universally recognized as the founding father of 
modern pedagogy' (Campi 2014: 259), 'a man of original genius' (Adamson 1921: 79), 'a one-man revolution' (Filkin 1975: 188, and 'that incomparable Moravian' (Murphy, 26; originally written by Cotton Mather after Comenius declined an invitation to join the administration of Harvard). Though history almost completely forgot him and his work for nearly two centuries, he stands as an exemplar of intellectual-theological leadership in the most difficult of times.

For all his accomplishments, he is not beyond criticism. One may observe in Comenius a nearly obsessive focus on some ideas, such as pansophy (universal wisdom), coupled with a desire to conform all things to this notion (Eby 1952: 180). A case could be made that pansophy may have held a position of central worldview presupposition for Comenius, alongside such foundational Christian beliefs as the image of God in man. His obsession with ideas such as pansophy is understandable, however, when viewed in the context of his largely unfulfilled ambitions. His attempts to establish a pansophic school, which he believed would lead to more pansophic schools, which would lead to the unification of the churches, which would lead to increasing world peace continued without completion throughout his life. The ideas that he wrote so passionately about in his 20 s, he was never able to fully put into practice. Thus they became the obsessions of a man who had the high hopes of bettering his embattled world. Sadler explains Comenius's situation well:

Nevertheless the highest loyalty of Comenius was not to any particular group but to the whole of mankind. The yearning for universal reform was the daemon that made his life dynamic and that tipped the scales in favour of the extraordinary in one who might otherwise have been 'a simple, good man' as Campagnac describes him. The history of reform is the comparison of fact with an idea and this constant comparison requires a prophetic urgency which Comenius possessed in a very high degree... This heroic yearning must be, at the personal level, his claim to greatness (Sadler 1966: 289).

Because of the wide range of interests and involvements that Comenius had throughout his life, and the near constant and simultaneous pursuit of all of them, it is challenging to explain his leadership succinctly. In the topical division of this article, I have attempted to examine four separate, but interrelated, streams of the intellectual-theological leadership of Comenius over the course of his lifetime. However, one final note should be made about the goals and hopes of John Comenius. He sought, above all, to facilitate the restoration of all things by the divine redemption of humanity from their sin. The idea that the image of God in humanity had far-reaching implications for education, society, religion, and politics permeates Comenius's work. Atwood writes, 
The idea that God created all things good and had made humankind in his own divine image meant that nature, including human nature, reflected the goodness of God, in spite of the existence of sin and corruption in the world... Redemption, for Comenius, was not simply the justification of the individual before the judgment seat of God; it was the restoration of the original blessing of creation (2009: 373-374).

Charisma or sheer influence can often be mistaken with good leadership. For the believer, leadership must be grounded in theological principles found in Scripture, exercised for the benefit of the church and the glory of God, and have the hope of God's promises as its ultimate vision. Though Comenius's efforts were constantly embattled, his intellectual-theological leadership is a legacy to a church that is now, and will always be until Christ returns, in need of leaders with conviction and compassion, undaunted by opposition, and who give their lives to a divine calling of influence. The rewards that Comenius reaped in this life were few, but the impact of the kind of leadership he displayed reaches far beyond this life.

\section{Bibliography}

Adamson JW (1921) Pioneers of Modern Education: 1600-1700. Cambridge: Cambridge University Press.

Atwood CD (2009) The Theology of the Czech Brethren from Hus to Comenius. University Park, PA: Pennsylvania State University Press.

Bock EC (1970) The Legacy of John Amos Comenius. Christianity Today (November issue): 11-14.

Comenius JA (1907) The Great Didactic. In Keatinge MW (trans and ed) The Great Didactic of John Amos Comenius. London: Adam and Charles Black.

Comenius JA (1942) The Labyrinth of the World and the Paradise of the Heart. Spinka M (trans). Chicago, IL: The National Union of Czechoslavak Protestants in America.

Comenius JA (1993) Panorthosia or Universal Reform: Chapters 19-26. Dobbie AMO (trans). Sheffield: Sheffield Academic Press.

Eby F (1952) The Development of Modern Education, second edition. Englewood Cliffs, NJ: Prentice-Hall.

Falkner WF (2001) Comenius, Johann Amos (1592-1671). In Anthony MJ (ed) Evangelical Dictionary of Christian Education. Grand Rapids, MI: Baker Academic.

Filkin WW (1975) John Amos Comenius (1592-1670). In Towns EL (ed) $A$ History of Religious Educators. Grand Rapids, MI: Baker Books. 
Gangel KO and Benson WS (1983) Christian Education: It's History and Philosophy. Chicago, IL: Moody Press.

Glenn J (2016) Toward a Contextual Theological Reading of John Amos Comenius. International Journal of Christianity E Education 20(3): 186-198.

Gundem BB (1992) 'Vivat Comenius': A Commemorative Essay on Johann Amos Comenius, 1592-1670. Journal of Curriculum and Supervision 8(1): 43-55.

Hábl J (2010) School as Workshop of Humanity: J. A. Komensky's Pedagogical Anthropology. Journal of European Baptist Studies 11(1): 36-40.

Hábl J (2011) Lessons in Humanity: From the Life and Work of Jan Amos Komensky. Bonn: Verlag für Kultur und Wissenschaft.

Hábl J (2015) Jan Amos Comenius and his 'Forging Place of Humanity'. Evangelical Review of Theology 39(2): 113-127.

Jelinek V (1953) The Analytical Didactic of Comenius. Chicago, IL: The University of Chicago Press.

Kinloch TF (1969) Pioneers of Religious Education. Freeport, NY: Books for Libraries Press.

Murphy D (1995) Comenius: A Critical Reassessment of his Life and Work. Portland, OR: Irish Academic Press.

Pelikán J (1992) The Place of John Amos Comenius in the History of Christian Theology. Communio viatorium 34(3): 5-18.

Price K (1962) Education and Philosophical Thought. Boston, MA: Allyn and Bacon.

Robinson E (1998) John Amos Comenius: Exemplar of Integration. Christian Education Journal 2(*): 45-57.

Sadler JE (1966) J. A. Comenius and the Concept of Universal Education. London: George Allen \& Unwin.

Smith D (2000) Gates Unlocked and Gardens of Delight: Comenius on Piety, Persons, and Language Learning. Christian Scholar's Review 30(2): $207-$ 232 